\title{
Makna Visual dalam Ilustrasi Naskah Sajarah Banten
}

\author{
Savitri Putri Ramadina, Yasraf Amir Piliang, dan Nuning Damayanti Adisasmito \\ Program Studi Doktor Ilmu Seni Rupa dan Desain, \\ Fakultas Seni Rupa dan Desain, \\ Institut Teknologi Bandung \\ Jl. Ganesha No. 10 Bandung \\ E-mail: sp.ramadina@gmail.com
}

\begin{abstract}
Sajarah Banten refers to a group of manuscripts about Banten Sultanate which was made around the $17^{\text {th }}$ to $19^{\text {th }}$ century. Among a total of 29 surviving manuscripts, there was only one with illustrations. The visuals did not depict any living beings and only consisted of inanimated objects such as ships, furnitures, buildings, and flags. Regardless, the objects' compositions indicated certain events and activities mentioned in the narration. This research aimed to scrutinize how the objects' visualizations and compositions without depictions of the characters were used to illustrate the story in Sajarah Banten. The method used in this research was qualitative analysis with visual semiotic approach by C.S. Peirce to understand how the objects' visual meanings were used to signify certain activities.
\end{abstract}

Keywords: Banten, illustration, manuscript, semiotics, visual.

\begin{abstract}
ABSTRAK
Sajarah Banten merujuk pada kumpulan naskah tentang Kesultanan Banten yang dibuat sekitar abad ke-17 hingga abad ke-19. Dari total 29 naskah yang bertahan dan sudah diteliti, hanya ada satu naskah yang memiliki ilustrasi. Visualisasinya tidak menyertakan gambaran mahluk hidup dan hanya terdiri dari benda mati seperti kapal, furnitur, bangunan, dan bendera. Meskipun demikian, komposisi objek-objek tersebut menandakan peristiwa dan aktivitas tertentu yang ada dalam narasi naskah. Penelitian ini bermaksud untuk menelaah bagaimana visualisasi dan komposisi objek tanpa penggambaran karakter digunakan untuk mengilustrasikan cerita dalam naskah Sajarah Banten. Metode yang digunakan adalah analisis kualitatif dengan pendekatan semiotika visual C.S. Peirce untuk memahami bagaimana makna visual pada obyek digunakan untuk menandai aktivitas tertentu.
\end{abstract}

Kata kunci: Banten, ilustrasi, naskah, semiotika, visual.

\section{PENDAHULUAN}

Ilustrasi merupakan gambar yang memvisualisasikan konsep serta ide kepada audiens dan pada dasarnya bersifat objektif. Fungsi ilustrasi antara lain adalah sebagai dokumentasi dan referensi visual, penyampaian cerita (storytelling), persuasi, dan identitas (Male, 2007, hlm 98). Dengan kata lain, ilustrasi memiliki hubungan erat dengan apa yang ingin disampaikan oleh pembuatnya, terutama pada naskah kuno yang umumnya berisi petuah atau cerita sejarah sehingga ilustrasinya berfungsi untuk menunjang aspek storytelling.

Tradisi pembuatan naskah di Indonesia telah dirintis sejak periode Hindu-Buddha pada abad ke-7 melalui prasasti-prasasti. Material yang umum digunakan adalah 
bahan organik seperti kertas dari lontar, daluang, kulit kayu, bambu, rotan, dan sebagainya (Kumar \& McGlynn, 1996, hlm. 70). Kegiatan pembuatan naskah kuno dilakukan di skriptorium (tempat pembuatan naskah) yang ada di lingkup keraton, pesisiran, dan mandala-mandala atau pusat keagamaan. Teks pada naskah biasanya dibuat oleh juru tulis, sementara jika ada gambar atau elemen visual lain dibuat oleh juru gambar sehingga antara teks dan visual seringkali tidak sama pembuatnya. Contohnya pada naskah kuno beriluminasi yang dibuat pada masa pemerintahan Paku Alam II (1830-1858) di Yogyakarta yang dibuat oleh tim yang terdiri dari pemrakarsa, juru tulis, juru baca, dan juru gambar (Saktimulya, 2016, hlm. 47).

Naskah-naskah kuno Indonesia umumnya tidak disertai gambar dan hanya sedikit yang memiliki ilustrasi atau iluminasi (hiasan dekoratif). Gaya visualnya dibentuk oleh semangat zaman, kondisi sosial budaya serta sumber daya yang tersedia, sehingga ilustrasi juga memiliki fungsi sosial untuk bisa dipahami oleh masyarakat yang menjadi audiensnya pada masa dibuatnya naskah tersebut (Adisasmito, 2012, hlm. 314). Ilustrasi pada naskah kuno Indonesia mulai ada sejak periode akhir Hindu-Buddha akhir, terutama pada era Kerajaan Majapahit hingga abad ke15. Naskah yang dibuat di Jawa dan Bali pada periode ini biasanya memiliki ilustrasi bergaya wayang beber. Selanjutnya pada abad ke-15 yang merupakan periode penyebaran agama Islam di Indonesia, kebutuhan naskah untuk kepentingan edukasi dan dakwah mendorong berkembangnya pembuatan naskah. Beberapa naskah terutama salinan mushaf Al-Quran serta surat-surat diplomasi kesultanan menggunakan iluminasi, sementara ilustrasi lebih sering digunakan pada naskah yang bersifat sekuler.

Naskah mulai dibuat untuk kepentingan komersil ketika Thomas Stamford Raffles mulai mengumpulkan naskah-naskah tradisional pada awal abad ke-19. Permintaan akan naskah-naskah untuk dikoleksi dan dibawa ke Eropa menjadikan banyaknya salinan naskah berilustrasi. Kegiatan pembuatan naskah mulai hilang sejak datangnya mesin cetak ke Indonesia pada abad ke-19, dan saat ini tradisi naskah yang masih bertahan terdapat di Bali (Kumar \& McGlynn, 1996, hlm. 151).

\section{Ilustrasi Naskah Sajarah Banten}

Kesultanan Banten merupakan kerajaaan bercorak Islam di daerah yang sekarang menjadi provinsi Banten dan sebagian Lampung. Pendirinya adalah Syarif Hidayatullah atau yang biasa dikenal sebagai Sunan Gunung Jati salah satu anggota Wali Sanga, serta putranya Maulana Hasanuddin pada tahun 1526 (Guillot, 2011, hlm. 15). Selama kurang lebih 3 abad dari tahun 1526 hingga 1813, Banten menjadi salah satu pelabuhan utama dan pusat perdagangan di pulau Jawa, serta salah satu pusat penyebaran agama Islam. Banten mulai mengalami penurunan setelah perang saudara antara Sultan Ageng Tirtayasa dan anaknya yang didukung Belanda, Sultan Haji pada tahun 1680-1683. Pada tahun 1808 sebagian wilayah Kesultanan Banten dianeksasi oleh Belanda dan tahun 1813 Kesultanan Banten resmi dihapus pemerintah kolonial Inggris yang masuk ke wilayah Indonesia. 
Sumber utama sejarah Kesultanan Banten berasal dari kumpulan naskah yang dibuat dalam rentang waktu yang beragam mulai dari awal berdirinya pada abad ke16 hingga setelah Banten menjadi bagian dari karesidenan Belanda pada abad ke-19. Kumpulan naskah tersebut secara kolektif disebut sebagai Sajarah Banten (selanjutnya disebut SB). SB kemudian dibagi lagi ke dalam dua kelompok sesuai dengan isi naskah: Sajarah Banten Besar (selanjutnya disebut SBB) memuat cerita yang bersifat 'mayor' dan mencakup sejarah Kesultanan Banten secara luas dan Sajarah Banten Kecil (selanjutnya disebut SBK) yang lebih ringkas dan biasanya hanya berfokus pada peristiwa tertentu. Jumlah naskah yang ada hingga sekarang adalah 29 naskah, tersebar baik di Perpustakaan Nasional Republik Indonesia, perpustakaan luar negeri seperti KITLV Belanda, dan koleksi pribadi (Pudjiastuti, 2015, hlm. 21-22).

Diantara 29 naskah SB tersebut, hanya ada satu yang memiliki ilustrasi yaitu naskah kode KBG 183 koleksi Perpustakaan Nasional Republik Indonesia. Naskah SB KBG 183 sebagai satu-satunya naskah yang memiliki ilustrasi diantara naskah SB lainnya akan menjadi fokus penelitian ini. Berdasarkan hal tersebut, penelitian ini akan merujuk pada naskah KBG 183 setiap kali membahas “ilustrasi naskah SB".

Naskah KBG 183 ditulis dengan aksara Arab Pegon di atas kertas Eropa berukuran sekitar A5 dan terdiri dari 87 halaman. Secara konten KBG 183 termasuk dalam kelompok SBK (Pudjiastuti, 2010, hlm. 4). Isinya menceritakan tentang silsilah para sultan
Banten yang ditarik dari Nabi Muhammad SAW, perang saudara antara Sultan Ageng Tirtayasa dan Sultan Haji dan diakhiri pengasingan Sultan Ishaq ke Batavia (Abul Nashar Muhammad Ishaq Zainulmuttaqin, sultan kedua terakhir Banten) oleh Belanda pada tahun 1808; dengan fokus utama naskah pada cerita Sultan Ageng Tirtayasa dan Sultan Haji. Berdasarkan jenis kertas dan akhir ceritanya, diperkirakan naskah ini dibuat paling cepat pada tahun 1808. Nama pembuat naskah atau patron yang menjadi pemrakarsa naskah tidak diketahui karena tidak dicantumkan.

Ilustrasi SB dibuat dengan tinta hitam, kuning, dan ungu atau biru yang sulit diketahui karena telah pudar. Tidak ada penggambaran mahluk hidup meskipun ceritanya berisi tentang tokoh-tokoh penting Kesultanan Banten. Sejauh ini belum ada penelitian tentang ilustrasi SB yang lebih detail. Kumar dan McGlynn dalam Illuminations: The Writing Traditions of Indonesia (1996, hlm. 115) membahas naskah SB secara sepintas, lebih terkait dengan konten dan meskipun menggunakan foto halaman naskah SB KBG 183 sama sekali tidak menyinggung ilustrasinya. Penelitian ini bermaksud untuk menelaah bagaimana cara penggambaran ilustrasi naskah SB, baik melalui gaya visual maupun komposisi gambar mampu melakukan tugasnya sebagai ilustrasi yang mendukung aspek storytelling naskah tersebut.

\section{METODE}

Metode penelitian kualitatif tentang karya seni memiliki dua strategi dasar. Pertama 
adalah dengan memperhatikan manifestasi fisik karyanya dan kedua melalui penjelajahan konteks latar yang terkait dengan faktor yang mendukung terwujudnya karya (Rohidi, 2011, hlm. 75). Salah satu pendekatan yang dapat digunakan dalam metode kualitatif analisis karya seni adalah semiotika.

Semiotika menurut Umberto Eco adalah "ilmu yang berhubungan dengan apapun yang dapat menjadi tanda"; dimana tanda dapat berupa kata, gambar, suara, dan objek (dalam Chandler, 2007, hlm. 2). Secara umum terdapat dua model analisis semiotika: berdasarkan Ferdinand de Saussure yang disebut model Saussurean dan berdasarkan Charles Sanders Peirce atau model Peircean. Karakteristik Saussurean terdiri dari dua unsur (dyadic): (1) signifier atau penanda yang merupakan bentuk dari tanda dan (2) signified atau penanda yang merupakan konsep yang dirujuk oleh tanda. Sementara model semiotika Peircean terdiri dari 3 bagian (triadic): (1) representamen yaitu bentuk dari tanda; (2) interpretant yaitu 'rasa' yang dibangun oleh tanda tersebut; dan (3) object yaitu sesuatu yang dirujuk tanda yang berada di luar tanda itu sendiri. Tanda dalam konsep Peircean merupakan kesatuan dari apa yang direpresentasikan (object), bagaimana Ia direpresentasikan (representamen), dan bagaimana hasil interpretasinya (interpretant).

Model Peircean memungkinkan untuk memperhatikan bagaimana mode-mode penanda yang berbeda bekerja, sementara model Saussurean hanya memperhatikan bagaimana sistem tanda bekerja (Iversen dalam Rose, 2016, hlm. 118). Berdasarkan pertimbangan tersebut, penelitian ini menggunakan model Peircean untuk dapat memahami bagaimana ilustrasi SB dapat mendukung narasi naskah tanpa menggambarkan karakter tokoh ceritanya.

\section{Semiotika Visual Peircean}

Tanda dalam konsep Peircean menjadi mediasi antara apa yang direpresentasikan, objeknya, dan interpretant (efek yang diproduksi tanda pada individu yang menginterpretasikannya) (Jappy, 2013, hlm. 4). Model Peircean yang umum digunakan dalam kajian visual terdiri dari 3 jenis tanda:

1) Icon: pada tanda yang bersifat ikonis, penanda merepresentasikan petandanya melalui 'kemiripan'.

2) Index: tanda yang bersifat indeksikal menunjukkan hubungan antarpenanda dan petanda yang memiliki hubungan makna terkait kebudayaannya atau sebab-akibat.

3) Symbol: tanda simbolis menunjukkan hubungan antar penanda dan petanda berdasarkan persetujuan tertentu yang bersifat arbitrer.

Analisis semiotika visual terdiri dari dua langkah. Pertama dengan menganalisis tanda secara individual. Tanda visual terlihat dari cara penggambaran: apakah secara ikonis, indeksikal, simbolis, dan bagaimana cara menyampaikan kode sosial dan idiom estetiknya. Kedua adalah analisis tanda yang membentuk teks. 'Teks' disini diartikan sebagai kombinasi tanda (Tinarbuko, 2016, hlm. 185). Langkah analisis semiotika visual penelitian ini dipaparkan pada Gambar 1. 


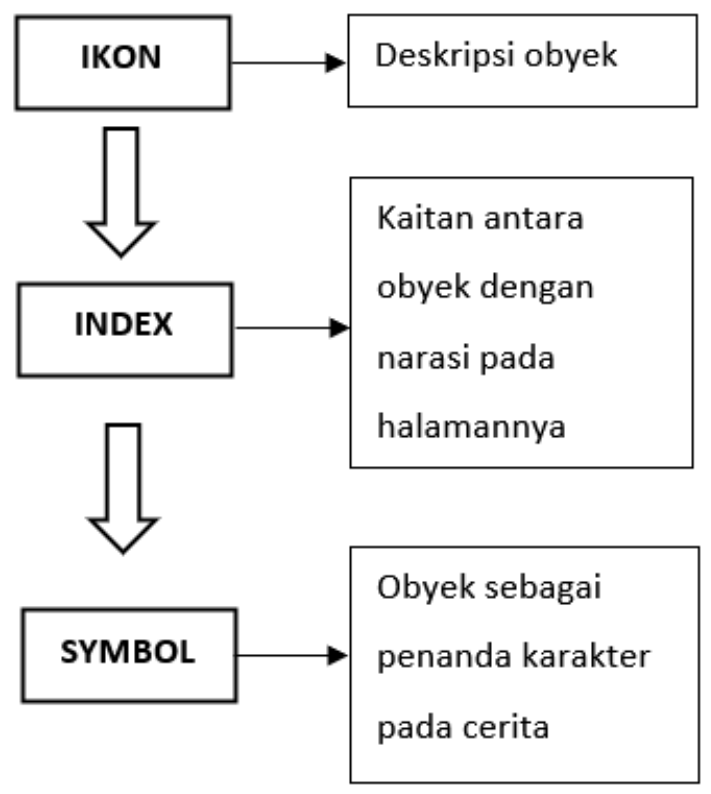

Gambar 1. Langkah Analisis (Sumber: Ramadina, 2020)

\section{HASIL DAN PEMBAHASAN}

Ilustrasi naskah SB yang dijadikan sampel penelitian sejumlah 5 halaman berilustrasi yang terdapat pada rentang halaman 19 hingga 30 pada naskah. Sampel diambil berdasarkan pertimbangan isi cerita pada halaman terkait, serta hubungannya dengan ilustrasi pada halaman tersebut. Pemaparan analisis ilustrasi berdasarkan semiotika visual dilakukan dengan memaparkan obyek visual sebagai icon, lalu kaitan antara obyek dengan narasi cerita (index). Jika tidak ada pada halaman yang berilustrasi, maka akan dicari kaitannya pada isi halaman sebelum atau sesudahnya. Terakhir dilakukan interpretasi terhadap simbolisasi yang terdapat pada obyek visual tersebut.

Cerita naskah pada halaman 19-30 yang dijadikan sampel berfokus pada awal mula konflik antara Sultan Ageng Tirtayasa (selanjutnya disebut SAT) dan anaknya yaitu Sultan Haji atau Pangeran Haji (selanjutnya disebut $\mathrm{PH})$. Berawal dari keberangkatan $\mathrm{PH}$

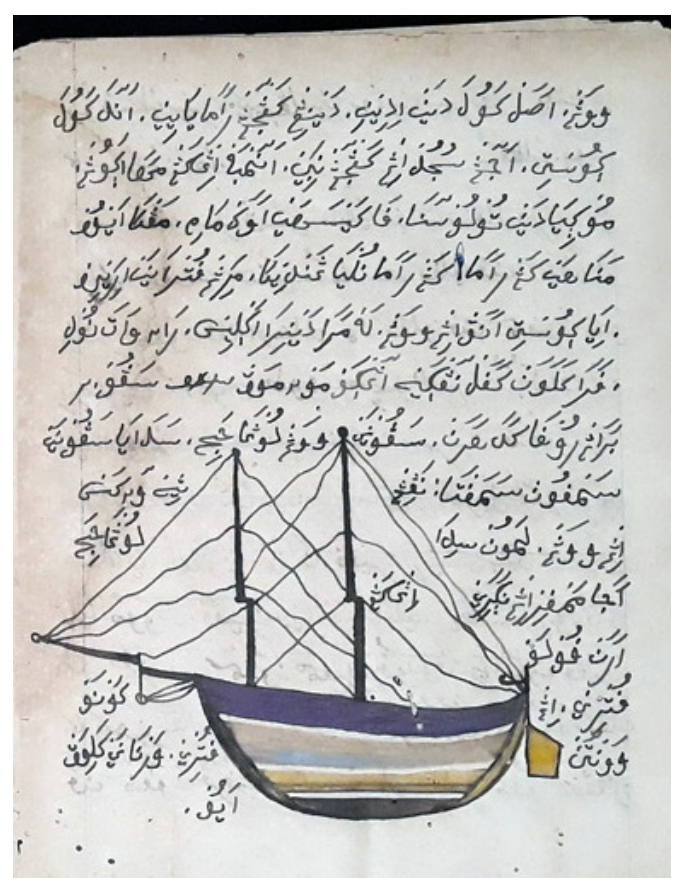

Gambar 2. Halaman 19 SB KBG 183 (Sumber: Ramadina, 2018)

ke Mekah untuk menunaikan ibadah haji, SAT berpesan agar ketika pulang PH tidak singgah kemanapun. Meskipun demikian, dalam perjalan pulang $\mathrm{PH}$ tertarik dengan seorang putri di pulau yang dilewatinya sehingga ia singgah untuk melamar. Kakak sang putri, Raja Pandita (selanjutnya disebut RP) bersedia merestui asalkan $\mathrm{PH}$ memberikan pakaian hajinya. RP kemudian menggunakan pakaian tersebut untuk menyamar dan mengaku sebagai PH. SAT yang menyadari bahwa itu bukan putranya tidak bersedia menemui. RP kemudian meminta bantuan Belanda untuk menyerang SAT karena tidak diakui. SAT berupaya meminta bantuan Inggris, tetapi ditolak karena tidak ingin ikut campur.

Analisis pertama akan dilakukan pada ilustrasi yang terdapat pada halaman 19 (perhatikan Gambar 2). Cerita pada halaman ini adalah ketika PH meminta izin untuk berangkat haji pada SAT. Terjemahan pada halaman ini adalah sebagai berikut: "[...] 
(tekad)kulasalkan hamba diijinkan/oleh ayahandal hamba mohon ayah/Hamba ingin bersujud di hadapan Nabi/menyembah Yang Maha Agung/ mohon ikhlaskanlah /kepergianku/maka bingung hati ayahnya. Ayahnya lalu berkata/dengan lirih pada putranya/baiklah anakku/ayo pergilah segeral bersiaplah segeraldan kapal/ penuhilah dengan bekal/barang-barang dan makanan/ bekal orang yang akan pergi haji/Semua bekal sudah disiapkan. Tetapi ada pesanku/jika kau jadi pergi haji/jangan singgah ke negeri/yang bernama Pulo Putri/disitu ada putrilyang wajahnya sangat [...] [cantik]" (Pudjiastuti, 2010, hlm. 76):

1) Icon: Ilustrasi berupa kapal tampak samping. Badan kapal dibagi 4 bagian dengan urutan warna dari atas: ungu, kuning/biru (tidak jelas karena pudar), kuning, dan ungu. Kapal memiliki dua tiang dengan tali layar, meski layar tidak terlihat terkembang. Pada bagian bawah buritan terdapat dayung/propeller berwarna kuning.

2) Index: pada teks objek "kapal" disebutkan dengan jelas, sehingga ilustrasi merujuk pada teks. Selain itu, disebutkan bahwa PH sedang bersiap untuk pergi, kapal belum berangkat sehingga layar digambarkan belum terkembang.

3) Simbol: Kesultanan Banten dikenal sebagai salah satu poros maritim Nusantara pada masa kejayaannya. Kapal sendiri merupakan salah satu objek yang cukup sering ditemui pada ilustrasi naskah SB. Warna yang digunakan untuk badan kapal yaitu ungu dan kuning merupakan warna yang sering diasosiasikan dengan

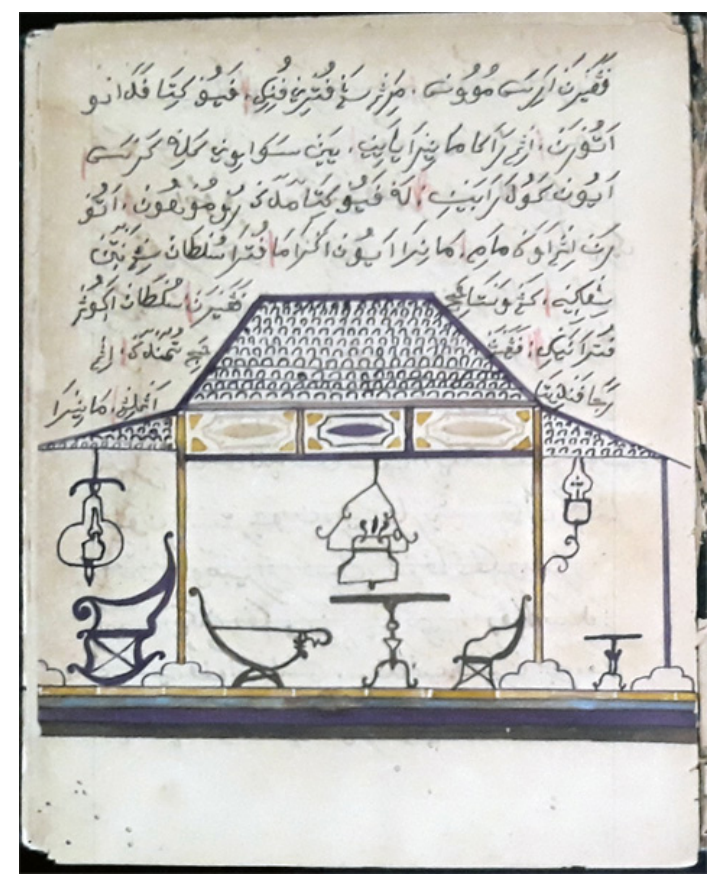

Gambar 3. Halaman 23 SB KBG 183

(Sumber: Ramadina, 2018)

warna kerajaan atau kekayaan. Selain itu, kapal bukanlah obyek yang murah untuk diproduksi. Kapal disini merepresentasikan karakter PH dan SAT yang merupakan penguasa Kesultanan Banten.

Hal yang menarik pada halaman ini adalah komposisi ilustrasi yang diletakkan tanpa ada batas yang jelas dengan teks, sehingga teks disusun mengikuti kontur obyek, dan ilustrasi terasa mendominasi halaman. Ada kemungkinan ilustrasi dibuat lebih dulu dari teks.

Kelanjutan cerita pada halaman 20-22 adalah kepulangan $\mathrm{PH}$ setelah menunaikan haji, kemudian singgah untuk meminang putri di suatu pulau. PH kemudian menghadap RP untuk meminang putri. Adegan tersebut dinarasikan pada halaman 23 (perhatikan Gambar 3).

Terjemahan pada halaman 23 adalah sebagai berikut: "Pangeran berkata pelan/kepada 
sang putrilayo kita sampaikan/pada kakakmu dinda/bahwa kita telah sepakat/kau mau aku nikahi. Ayo kita menghadap dulu/katakanlah bahwa akul (yang) akan menikahimu/putra sultan Banten/ yang bernama Pangeran Haji/putra Sultan Agung. Pangeran Haji mendekat/kepada Raja Pandhita (dan) berkata/Anda [...]" (Pudjiastuti, 2010, hlm. 79). Analisis pada ilustrasinya:

1) Icon: obyek berupa bangunan seperti pendopo, di bagian atap terdapat lis dekoratif dengan warna kuning dan ungu. Terdapat 3 buah lampu, 3 buah kursi dan 2 buah meja bergaya Eropa. 2 lampu menggantung dari atap dan 1 menempel di tiang atau dinding bangunan. 1 kursi terletak di bagian luar kiri dan 1 meja di bagian luar kanan. Di bagian tengah/dalam 2 kursi saling berhadapan dengan 1 meja diantaranya, 1 lampu menggantung diatas meja.

2) Index: 3 kursi kemungkinan merujuk pada teks yang menyebutkan 3 karakter yaitu putri, PH, dan RP. Posisi kursi yang saling berhadapan menunjukkan interaksi antar 2 orang, dan pada teks disebut bahwa $\mathrm{PH}$ akan menghadap $\mathrm{RP}$ untuk melamar putri.

3) Simbol: bentuk, besar, dan posisi kursi, meja, lampu yang berbeda kemungkinan menunjukkan ketiga karakter yang disebut pada teks. Ada dua karakter yang punya kekuatan, yaitu $\mathrm{PH}$ sebagai penerus Kesultanan Banten, dan RP yang dimintai restu oleh $\mathrm{PH}$ untuk menikahi putri. Selain itu ada dua interaksi pada teks: ketika PH berbicara dengan putri, dan ketikaPHakan menghadap RP. Disini RP memiliki posisi paling tinggi karena dia yang dimintai restu; kemungkinan kursi paling besar di luar kiri adalah RP. Sementara kursi kedua terbesar ditengah dan kursi yang dihadapannya adalah $\mathrm{PH}$ dan putri yang sedang berbincang. Posisi $\mathrm{RP}$ dan PH saling bertolak belakang dihalangi dinding. Terdapat lampu diatas $\mathrm{RP}$, mengisyaratkan RP yang 'terang' terhadap situasi; sementara PH dan putri berbagi 'cahaya informasi' yang sama.

Seperti pada ilustrasi halaman 19, teks mengikuti kontur ilustrasi meskipun dengan susunan yang lebih rapi karena tidak ada teks diantara gambar.

Cerita berikutnya pada halaman 27 adalah ketika RP meminta bantuan Belanda agar diakui sebagai PH. Terjemahan teksnya adalah sebagai berikut: "[...] sudah mendarat/ dari kapalnya di Betawi/lalu ia bertemu dengan/ Gubernur Jenderal Idler Semit. Raja Pandhita berkata/kepada Jenderal Idler Semit/wahai tuan aku/baru saja pulang dari haji/dan aku ini adalah putra sultan/kerajaan Banten. Tuan aku datang (padamu)/(sebab) bagaimana aku ini/jika tidak [...]" (Pudjiastuti, 2010, hlm. 81). Berikut analisis ilustrasinya (perhatikan Gambar 4):

1) Icon: objek bangunan seperti pendopo dengan ornamen di atapnya dan tiang bendera di sebelah kanan. Bagian dalam bangunan terdapat 3 kursi, 1 meja, 1 lampu gantung dan 2 lampu yang menempel di tembok, serta 2 bentuk kotak yang kemungkinan adalah jendela. Bagian bawah gambar terdapat caption dengan aksara Pegon bertuliskan "kantor jendral".

2) Index: teks menceritakan adegan perundingan antara RP dengan 


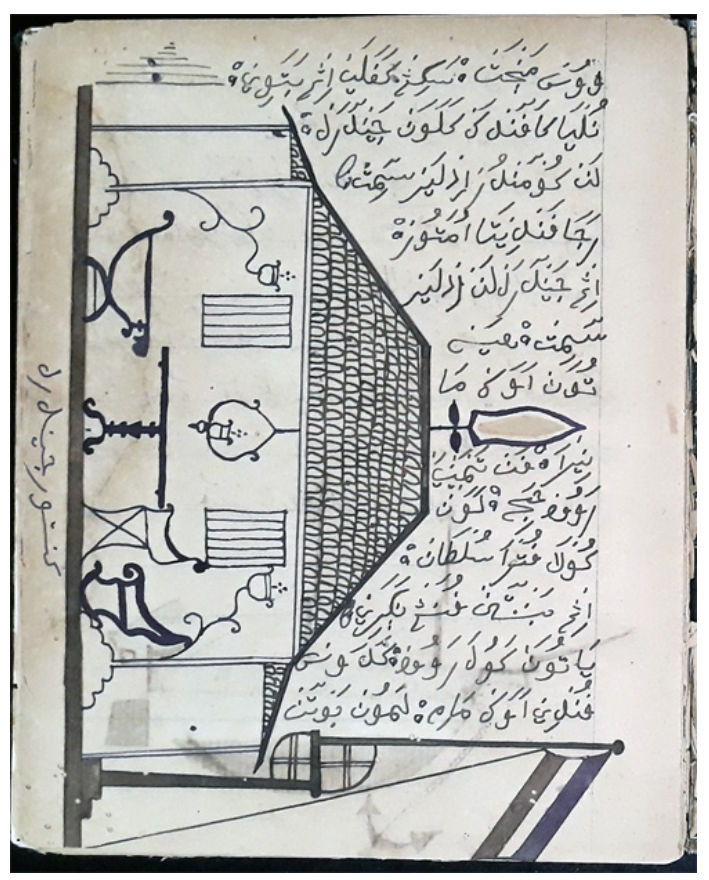

Gambar 4. Halaman 27 SB KBG 183

(Sumber: Ramadina, 2018. Foto diambil di Perpustakaan Nasional RI pada 12 Mei 2018.)

Gubernur Jendral Belanda yang bernama Idler Semit, sehingga 2 kursi yang berhadapan mungkin merujuk pada aktivitas tersebut. Bendera pada tiang diwarnai (urutan dari atas) ungu, putih, dan hitam. Warna tersebut mewakili value warna bendera Belanda (merah, putih, biru) karena pada naskah tidak digunakan tinta merah; kemungkinan ilustrator menggunakan tinta yang tersedia. Pada 3 lampu ada bentuk 4 titik hitam yang menunjukkan nyala lampu.

3) Symbol: Posisi Idler Semit paling kuat karena dia yang dimintai bantuan oleh RP dan karena perundingan dilakukan diteritorinya (caption "kantor jendral") sehingga mungkin diwakili kursi paling besar. Hal yang menarik di sini adalah 2 kursi yang diberi outline tebal dan 1 kursi dengan outline tipis. Teks halaman hanya menunjukkan 2 karakter (RP dan Idler Semit); logikanya seharusnya hanya ada 2 kursi. Posisi kursi 'tipis' menempel meja dan tepat dihadapan kursi lainnya, bisa jadi menunjukkan dualitas RP yang mengaku sebagai $\mathrm{PH}$.

Ilustrasi dan caption pada halaman 27 ini ditempatkan secara vertikal dan teks dibuat dengan mengikuti kontur gambar. Pada baris ke-11 bahkan teks bersinggungan langsung dengan outline gambar. Mungkin gambar dibuat lebih dulu dengan posisi kertas landscape atau horizontal sebelum ditulis teks dan teks akhirnya berupaya menyesuaikan.

Kelanjutan cerita pada halaman 28 adalah tentang persetujuan kerjasama antara Belanda dan RP yang mengaku sebagai Sultan Haji/PH, serta kembalinya RP ke Banten. Berikut terjemahan teksnya: "[...] diakuil karena hamba sudah lama (pergi)/jika negara kacaulaku minta tolong. Tuan jenderal berkata manis/kepada Sultan Haji/jika tidak diakui/kau segera (datang padaku)/aku akan menolong/ jika aku dibayar. Sultan Haji berkata cepat/ya akan kubayar/jika jenderal membantu/jika nanti negara kacau/iyalah nanti akan/aku bayar dengan kerajaan. Sesudah menyepakati perjanjian/Sultan Haji segera/kembali ke kapalnya/tak lama tiba di pelabuhan" (Pudjiastuti, 2010, hlm. 81). Analisis ilustrasinya (perhatikan Gambar 5) adalah sebagai berikut:

1) Icon: objek berupa kapal dengan 2 tiang bertali dan jangkar dengan rantai yang tersambung ke kapal. Terdapat semacam ornamen pada bagian buritan dan dibawahnya terdapat dayung/propeller. Badan kapal dibagi 4 bagian (dari atas): warna ungu dengan motif elips warna putih, biru yang sudah pudar, kuning, 


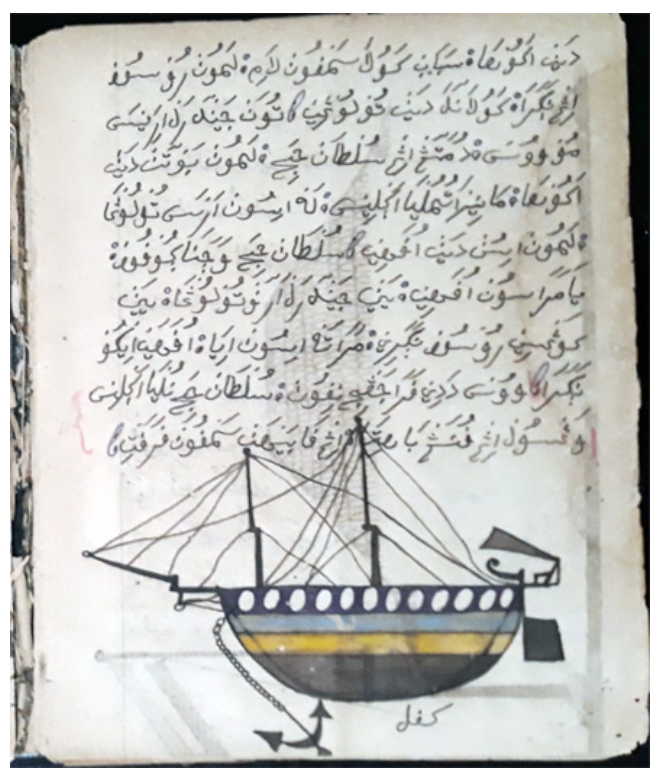

Gambar 5. Halaman 28 SB KBG 183 (Sumber: Ramadina, 2018)

dan hitam. Bagian bawah obyek terdapat caption beraksara Pegon bertuliskan "kapal".

2) Index: pada teks disebutkan aktivitas kembalinya RP ke kapalnya yang ada di pelabuhan. Teks tidak menyebutkan jika kapalnya sudah berlayar, karenanya layar tidak digambarkan dan jangkar masih turun karena kapal masih dalam kondisi berlabuh.

3) Symbol: jika dibandingkan dengan kapal yang digunakan $\mathrm{PH}$ untuk berangkat pada Gambar 2, kapal RP terlihat memiliki dekorasi dan ornamen yang lebih mewah, seakan menunjukkan perbedaan sifat $\mathrm{PH}$ yang sederhana dan agamis ketika berangkat untuk menunaikan ibadah haji dan RP yang ambisius ingin mengambil posisi PH sebagai pewaris Kesultanan Banten melalui kerjasama dengan Belanda dan kemewahan kapalnya merupakan cara untuk menunjukkan legitimasi kebangsawanan.
Pada halaman 28 terlihat pemisahan bagian antara teks dan gambar yang lebih jelas karena teks tidak mengikuti kontur gambar seperti pada ilustrasi-ilustrasi sebelumnya. Meskipun demikian, teks baris terakhir masih bersinggungan dengan gambar (bagian tiang layar).

Ilustrasi selanjutnya pada halaman 29 memiliki sedikit hubungan dengan teks pada halamannya, tetapi teks pada halaman berikutnya yang tidak berilustrasi menunjukkan aktivitas yang diwakili dalam ilustrasi. Terjemahan teks halaman 29 adalah: "Lalu segera merapat/di pelabuhan, Sultan Haji/ ingin bertemu dengan ayahnyalyang bernama Sultan Agung/tetapi nanti Sultan/tidak mau tahu. (Sultan Haji) sudah berada di alun-alun/ (tapi) Sultan Agung tidak mau menemui/sudah beberapa hari/[...]", sementara terjemahan teks pada halaman 30 adalah: "[...] pintu Sultan tetap terkunci/para prajurit kebingungan/ melaporkan kepulangan Sultan Haji. Sudah lama dia menunggu/tapi tidak ditemui/semua prajurit/ sudah ada yang ikut pada Sultan Haji/kemudian pada suatu hari/Sultan Haji ke Betawi. Segera dia mendekat/Sultan Haji ke Betawi/lalu bertemu dengan jenderal/sudah berkata Sultan Haji/kepada tuan jenderal/kita sudah membuat perjanjian/ bahwa tuan akan menolongku. Aku sudah lama duduk/tetapi aku tak ditemui/bahkan sudah beberpa hari/aku tetap belum ditemui/jika jenderal akan membantul inilah saatnya" (Pudjiastuti, 2010, hlm. 82).

Analisis ilustrasi pada halaman 29 (perhatikan Gambar 6) adalah sebagai berikut:

1) Icon: objek berupa bangunan dengan 2 dinding/pintu dekoratif di bagian kanan dan kirinya. Atap berbentuk segitiga 


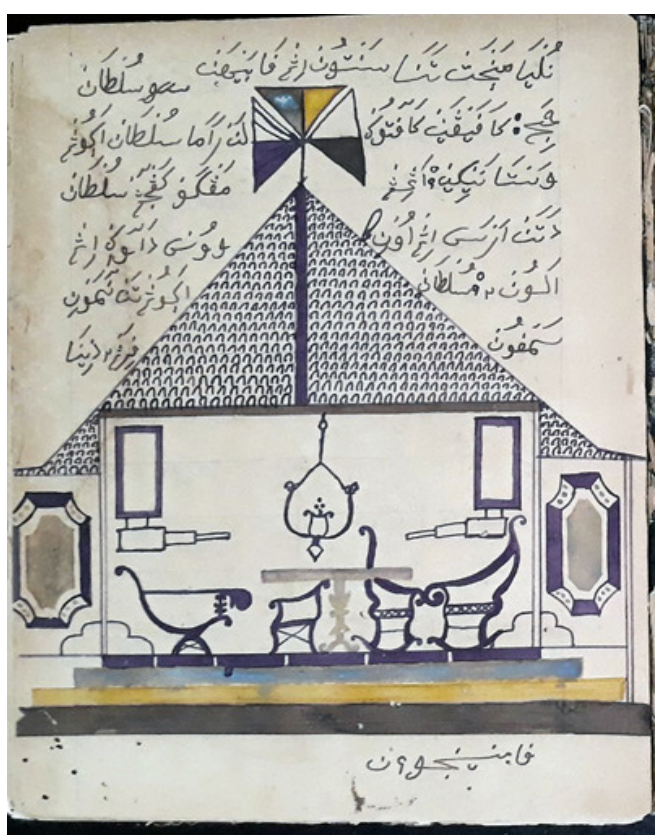

Gambar 6. Halaman 29 SB KBG 183 (Sumber: Ramadina, 2018)

dengan ornamen berupa tiang yang di atasnya terdapat 3 bendera/objek bentuk segitiga masing-masing dengan 2 warna: segitiga kanan warna putih dan ungu, segitiga kiri warna putih dengan 2 garis dan ungu, segitiga atas warna ungu atau biru yang sudah pudar (kiri) dan kuning (kanan). Bagian dalam bangunan terdapat 4 kursi 1 meja, 1 lampu gantung di tengah, dan 2 objek yang kemungkinan lampu cempor/ minyak. Bagian bawah gambar terdapat caption beraksara Pegon bertuliskan "panenjoan" atau tempat melihat.

2) Index: teks halaman 29 menunjukkan aktivitas RP dilakukan di alun-alun, sementara ilustrasi menunjukkan gambar bangunan "panenjoan". Meskipun demikian teks pada halaman 30 menceritakan bahwa RP "sudah duduk lama menunggu". Kegiatan duduk lama menunggu tersebut diwakili dengan 4 kursi, masing-masing memiliki model dan posisi yang berbeda. Dalam teori Bahasa Rupa yang dipaparkan oleh Primadi Tabrani (Tabrani, 2009, hlm. 8), objek yang digambarkan secara berulang-ulang menandakan adanya perubahan kegiatan. Perbedaan tersebut bisa menunjukkan adanya perubahan pergerakan RP dari waktu ke waktu ketika sedang menunggu SAT. Alternatifnya adalah adanya dua kegiatan yang dilakukan RP; pertama menunggu SAT, kedua adalah diskusinya dengan 'tuan jenderal' yang diwakili dua set kursi yang berhadaphadapan.

3) Symbol: set kursi berhadapan di bagian kiri memiliki perbedaan model, besar, dan jarak yang cukup signifikan, seakan mewakili SAT sebagai penguasa Banten dan RP yang hanya berpurapura menjadi PH. Sementara set kursi di bagian kanan memiliki model yang hampir serupa dan posisinya saling bersentuhan, menunjukkan kedekatan dan kerjasama RP dengan Belanda.

Ilustrasi halaman 29 memiliki dua alternatif interpretasi: apakah ilustrasi mewakili satu aktivitas, atau ilustrasi mewakili hubungan antar karakter. Teks mengikuti kontur ilustrasi bangunan seperti pada halaman 23 dan 27 (Gambar 3 dan 4).

\section{SIMPULAN}

Ilustrasi pada naskah Sajarah Banten menggunakan penempatan objek pada posisi tertentu untuk memaknai aktivitas yang dilakukan oleh karakter pada teks yang ada 
pada halaman tersebut. Contohnya pada adegan perundingan (Gambar 3, Gambar 4, dan Gambar 6), kursi ditempatkan berhadapan karena secara umum itulah posisi yang dilakukan ketika ada dua pihak yang berdiskusi.

Pada ilustrasi kapal meskipun tidak terlihat laut atau pelabuhan, layar yang tidak dikembangkan (Gambar 2) dan jangkar yang masih diturunkan (Gambar 5) dapat mengindikasikan bahwa kapal masih dalam posisi berlabuh atau belum berlayar.

Penggunaan caption untuk menjelaskan objek pada naskah SB bersifat arbitrer karena beberapa ilustrasi menggunakannya sementara ilustrasi lain tidak. Bisa saja caption digunakan hanya untuk menerangkan pertama kali dan selanjutnya tidak digunakan, tetapi di sini contohnya ilustrasi kapal yang muncul lebih dulu pada halaman 19 (Gambar 2) tidak menggunakannya, sementara ilustrasi berikutnya di halaman 28 menggunakan caption 'kapal'.

Makna simbolis pada ilustrasi naskah SB ditunjukkan melalui perbedaan tipe bendanya. Misalnya bentuk kursi yang berbeda-beda pada Gambar 3, Gambar 4, dan Gambar 6 digunakan untuk menunjukkan siapa karakter yang dimaksud berdasarkan status dan kepentingan mereka dalam aktivitas yang dipaparkan dalam teks terkait; atau pada perbedaan jenis kapal yang digunakan oleh PH dan RP. Meskipun demikian, tidak tertutup kemungkinan bahwa ilustrator naskah hanya sekedar menggambarkan objek sesuai yang dia bayangkan ketika membuat halaman tersebut. Hal ini membutuhkan penelitian lebih lanjut terkait jenis perabot dan kapal yang digunakan oleh Kesultanan Banten.

Hal lain yang menarik untuk diperhatikan dan dapat dielaborasi untuk penelitian selanjutnya adalah posisi Banten sebagai salah satu pusat penyebaran agama Islam di pulau Jawa. Salah satu karakteristik seni rupa Islam adalah anikonisme atau kecenderungan untuk tidak menggambarkan mahluk hidup (Al-Faruqi, 2000, hlm. 209), sehingga ada kemungkinan ilustrasi naskah SB tidak menggambarkan karakter sebagai manifestasi karakteristik tersebut.

\section{UCAPAN TERIMA KASIH}

Terima kasih penulis haturkan kepada promotor dan pembimbing penelitian disertasi: Prof. Dr. Yasraf Amir Piliang, MA.; Dr. Nuning Damayanti Adisasmito, Dipl.Art.; Dr. Pindi Setiawan, M.Si. Terima kasih pula teruntuk Prof. Dr. Titik Pudjiastuti, M.Hum., selaku narasumber penelitian ini.

\section{DAFTAR PUSTAKA}

Adisasmito, Nuning Y. D. (2012). Wujud Visual Gambar pada Naskah Tua Nusantara Sebagai Refleksi Intelektualitas Leluhur Bangsa. Panggung, 22 (3), 306-318.

Al-Faruqi, I. \& Al-Faruqi, Lois L. (1986). The Cultural Atlas of Islam. Diterjemahkan oleh Hasan, I. (2000). Atlas Budaya Islam. Bandung: Mizan.

Chandler, D. (2007). Semiotics: The Basics (2 ${ }^{\text {nd }}$ Edition). New York: Routledge.

Guillot, C. (2011). Banten: Sejarah dan Peradaban Abad X-XVII. Jakarta: Kepustakaan 
Populer Gramedia.

Jappy, T. (2013). Introduction to Peircean Visual Semiotics. London: Bloomsbury.

Kumar, A. \& McGlynn, John H. (1996). Illuminations: The Writing Traditions of Indonesia. Jakarta: Lontar Foundation.

Male, A. (2007). Illustration: A Theoretical \& Contextual Perspective. Switzerland: AVA Publishing SA.

Pudjiastuti, T. (2010). Sajarah Banten: Suntingan dan Terjemahan Teks KBG 183. Jakarta: Perpustakaan Nasional RI.

Pudjiastuti, T. (2015). Menyusuri Jejak Kesultanan Banten. Jakarta: Penerbit Wedatama Widya Sastra.

Rohidi, Tjetjep R. (2011). Metodologi Penelitian Seni. Semarang: Penerbit Cipta Prima Nusantara.

Rose, G. (2016). Visual Methodologies: An Introduction to Researching with Visual Materials (4 $4^{\text {th }}$ Edition). London: SAGE Publications Ltd.

Saktimulya, Sri R. (2016). Naskah-naskah Skriptorium Pakualaman: Periode Paku Alam II (1830-1858). Jakarta: Kepustakaan Populer Gramedia.

Tabrani, P. (2009). Bahasa Rupa. Bandung: Penerbit Kelir.

Tinarbuko, S. (2016). Semiotika Tanda Verbal dan Tanda Visual Iklan Layanan Masyarakat. Panggung, 26 (2), 181-194. 